\title{
DIE CHRISTEN SE ANTWOORD OP DIE KOMMUNISTIESE AANSLAG *
}

DAAR is ' $n$ vyand wat nou nie eers meer buite ons grense is nie, wat al hoe meer onbeskaamd is in sy woorde en optrede. Ons self het al veel te ly gehad onder die openlike aanslag teen ons instellinge. Enkele dekades is hierdie vyand al besig om sy aanslag te beplan en dikwels het hy al skyngevegte gelewer.

Dit het waarlik tyd geword dat ons saamkom om planmatig ook ons eie verweer te beplan en te sien of ons nog almal weet wat ons taak is. Die tema van hierdie kongres is nie maar net Kommunisme nie. Dan sou dit 'n studiekongres gewees het en sou ons in besadigdheid ons daarmee kon besig hou. Die tema is een wat ontstel, wat aangryp, wat roep tot paraatheid.

Luister: Die wese, die metodes, die program en die aanslag van die kommunistc. U merk seker ook wel dat hierdie optrede al nader kom, voelbaar nader, want dit eindig nie voor by die daadwerklike aanslag gekom is nie. Daar is ons nou reeds. Die tyd van beplanning is verby en daardie vyand het sy eerste houe al geslaan. Dit is alles goed en wel om te weet in welke rigting die vyand beweeg en waar die aanslag verwag kan word; om te weet welke wapens hy tot sy beskikking het en wie sy soldate is; om die spioene dop te hou wat geleidelik insypel om agter eie linies te kom en uit te vind wat in ons eie kring beplan word. Suid-Afrika is sekerlik dankbaar dat hierdie kongres gehou word, sodat die allereerste gedoen kon word: ons moes ons vyand ken en alles wat ons spioene van hom kon te wete kom. Gelukkig is dit nie die eerste maal wat hierdie vyand na vore kom nie en gelukkig is dit nie die enigste plek waar hy sy aanslae mak nie. Ons kon leer by ander lande en volke en is hartlik dankbaar dat ons medestryders het wat nie maar net met ons simpatiseer nie, maar met ons wil saamstry. Hulle is werklik ook oor ons bekommerd, omdat hulle juis bewus is van die ondergrondse, die bekruipende slinksheid van hierdie vyand. Sy metodes, wat al geweldig gewissel het, is tog eenders in toepassing. 'n Mens wonder net wanneer verantwoordelike volkere sal ophou om hulle ore te sluit en hulle harte en ons aan hierdie Suidpunt sal bly beskou as ,expendable”, gewerp as prooi vir die groot Beer. Wat 'n kortstondige beleid om vir die huidige die oog te sluit, of liewer met die skeel-oog na die kant van die Kommunisme te staan en met die oop oog te probeer ontleed wat alles met felle kritiek kan veroordeel word in Suid. Afrika. Hierdie beleid gaan dit nie net uiters moeilik maak vir daardie lande om die Kommunisme van hulle agterdeur af te hou nie, maar definitief onmoontlik.

Hierdie kongres roep ons in Suid-Afrika op tot stryd saam met die enkele bondgenote uit ander lande wat ons van harte by ons verwelkom, en ons hulde aan al die ander wat as eenlinge saam met ons stry binne hulle volkere.

* Verskyn in: Christendom teen Kommunisme. Referate gelewer by die Volkskomgres oor Kommunisme, Pretoria 1964, 237 - 257. 
Nou het $\mathrm{u}$ aan my opgedra om te luister en om onder die besef van ons reusetaak enigsins 'n opgawe te maak van ons weerbaarheid. Ek moet $u$ nie lei na die paradegronde van ons jongmanne wat hulle stel in diens van land en volk nie. Ek moet nie die knaphandigheid van ons veiligheidsdiens lof toeswaai nie. Dit word dag na dag en nag na nag gedemonstreer en word selfs deur die vyande erken. Ek moet $u$ ook nie lei na ons wakker landsregering met 'n vaste hand aan die stuur en wat nie mislei word deur die deursigtelike besluite van die Verenigde Volke Organisasie nie en die gul aangebode hulp graag gun aan lande wat dit werklik nodig het. Ek moet aan u voorhou die grondkapitaal van elke vorm van weerbaarheid van enige volk wat waardiglik sy land wil verdedig en wat, hoe klein hyself ook al is, tog in staat sal wees om met eer uit die stryd te tree. Ek moet aan $u$ voorhou die sluimerende en tog bewuste kragte binne die volksiel wat sy eintlike adel uitmaak, wat nie maklik swig voor die skerpgemikte aanvalle van 'n sluwe vyand nie. Ek moet aan u weergee watter kragte daar skuil in ons volksiel wat hom nog telkens in staat gestel het om as oorwinnaar uit die stryd te tree, ook toe hy teen baie magtige vyande om sy behoud, om sy siel moes stry. Wat ' $n$ heerlike en ook maklike taak. Dit is nie die eerste keer dat benoudheid oor ons toesak nie en dat grypende hande, moordende planne en getalleoorwig ons benou nie. Dit het ons gelouter, maar ook geleer. Dit het ons neergewerp en baie het gedink dat dit met ons uit en gedaan is, maar ons het weer opgestaan. En dit het só gou geskied dat dit vir baie soos 'n wonder was. Daar het nie stilte gekom oor Suid-Afrika na die slag van Bloedrivier nie. Daar het nie die gees van verslaendheid oor ons land gekom na die vryheidsoorlog aan die begin van hierdie eeu nie. Afrikaans is nie uitgeroei uit die tale van die Weste na doelbewuste poginge daartoe nie en ons landsekonomie het eerder met rasse skrede ontwikkel nadat ons beskinder is as 'n volk wat geen besigheidssin het nie. Ons het nog telkens geantwoord met 'n veel harder slag as die waarmee ons geslaan is. Ons het alles en nog veel meer terugontvang as dit wat van ons ontneem is.

Dit kan 'n mens trots en hoogmoedig maak, maar dit moet nie. Hierdie grondkapitaal van ons volk wat die regering kan versterk in sy optrede, wat die weermag verheug omdat daar gedetermineerdheid is, onkreukbare trou, hierdie geheime reserwe is nie van eie maksel nie, is nie ons eie krag nie, maar is ontvange genade, is Goddelik van oorsprong. Ek wil dit tipeer en daarop wys dat dit enkel en alleen Gods goedheid is wat ons volk en sy enkelinge so begenadig het dat ons tot sover gekom het. Immers, daarvan getuig tog seker elke monument wat uit die geskiedenishoogtepunte ons wil bemoedig. Dink aan die Vrouemonument met die naald vertikaal na bo gerig en met die oog van die moeder wat op ' $n$ vaste punt daarvoor gerig is, hoe groot haar ellende ook huidig mag wees. U kan ook na Pretoria kom met sy Voortrekkermonument, wat in sy hele vorm spreek van gebed en offer, van toewyding van al wat ons is en het aan God, omdat dit alles ontvange genade is. Dis genoeg. Ons erken dit almal. 
Ek moet weergee wat die antwoord van die Christen is in hierdie tydsgewrig. Ek verkies om liewer te spreek van die antwoord van dic gelowige, omdat elke gelowige 'n Christen moes wees, maar elke Christen deesdae nie meer 'n gelowige is nie.

Die gelowige kan sy antwoord heel gepas in drie dele weergee wat in kern sy onoorwinlikheid ook beklemtoon: $\mathrm{Ek}$ wil dit in drie Latynse woorde weergee wat samevattend is van ons roeping. Ons moet optree as

I. CONSERVATORIUM.

II. OBSERVATORIUM.

III. LABORATORIUM.

\section{Conservatorium.}

Die gelowige is van huis uit 'n bewaarder van 'n erfenis wat hy moet oorlewer. Alles wat hy doen, doen hy in die geloof of uit die geloof. Hy doen dit ook nie vir die eerste keer op so 'n wyse nie, maar hy leef uit die verlede en het hoogagting vir sy volk se geskiedenis. Hy is ' $n$ bewaarder van die allerbeste uit daardie geskiedenis en wortel juis in daardie verlede.

Die eerste wat ons geroep word om te bewaar, en dit besiel ons in elke stryd en vuur ons aan om te bly stry, is ons roeping. Dit wil nie sê dat dit net ons volk is wat 'n roeping het in sy land nie. Elke volk het in sy land 'n roeping en as hy nie ' $n$ roeping het nie, is sy verband tot daardie land maar lossies. Ons praat van ons tradisies en bedoel daarmee tog immers daardie dinge wat deur die vorige geslagte bewaar is en nou oorgelewer is, met die beste verwagting dat dit deur die nageslagte in ere bewaar sal word. Die grootste en mooiste wat ons in ons tradisie het, is dat ons voorgeslagte van die oomblik dat hulle hul voet laat druk het op Suid-Afrika se bodem, geweet het, gewis geglo het, dat hulle hier 'n roeping het. Dit kom reeds vroeg uit in hul optrede en uitsprake. As Jan van Riebeeck hier land, bid hy in die besef dat God hom geroep het om die Gereformeerde godsdiens in hierdie land te kom verbrei. Hy was nie maar net handelaar nie, maar het geestesgoed met hom saamgebring wat hier voort. geplant moet word.

Geen wonder nie, dat dit slegs 'n dekade geduur het en toe was daar al die uitroep dat die roeping so heftig was dat vreemdelinge hulle gebonde gevoel het aan hierdie land. Hulle was nie meer Hollanders nie, maar het Afrikaners geword.

En van nou af staan altyd duideliker in ons geskiedenis geskryf die woord roeping. Hierdie selfde woord bring 'n mens in oneindige moeilikhede. As hy nie daar was nie, sou dit wel moontlik wees dat 'n gans ander geskiedenis geskryf sou word. Waarom al die ellende en smart trotseer met 'n Engelse goewerment, met kafferoorloë op die grense, met moord om elke draai en dan geen vooruitsig op 'n rustige lewe nie? Waarom die Groot Trek met al sy ontberinge, met grafte oor ons wye velde? Dit bring tog nie rus nie, maar eerder gevare. Waarom Kaapland en Natal en toe Transvaal en die Oranje Vrystaat met hulle geskiedenisse? Wel, die Voortrekkers antwoord: God roep na die binnelande. Suid-Afrika het ons nodig. Dit skyn byna asof die ge- 
skiedenis van ons volk soms dreig om op te hou. Uitwissing het ons voor die oog duidelik geskryf gestaan. Daar was, wat getalle betref, geen toekoms nie.

Al wat daar was, was roeping. Duidelike roepingsbesef teenoor die inboorlinge van hierdie land, wat ook mekaar wou uitwis; 'n duidelike roeping teenoor 'n donker hinterland wat 'n beskawing moet dra wat betekenisvol moet wees vir Suidelike Afrika en die donker binnelande van Midde-Afrika. Die roeping gaan verder: hy het 'n woord ook vir die Christendom van Europa en Amerika, vir Christene oor die hele aarde. Dit is 'n roeping om te leef soos Christene en om aan ander van harte te gun om te leef soos Christene. Dit moet verkondig word, maar ook uitgeleef word.

In die tweede plek moet ons benadruk dat hierdie roeping 'n volk telkens in die moeilikheid beland, probleme laat opkom. Dit is miskien veels te swak uitgedruk, want dit is nie probleme wat beredeneer kan word nie, maar dit is krisisse wat soos onoorkombare berge in jou pad voor jou verrys, omdat magtige elemente, van verskillende aard en soort reg in jou pad staan. Jy kan daar nie verby nie, maar moet net verder. Soms is dit vyandige volke wat ontelbaar meer in getal is en nie net dreig nie, maar werklik aanstorm en nie spaar nie. Soms is dit jou eie onherbergsame en kiembelaaide woeste wêreld wat jouself en jou vee wegmaai.

Ook hier moet ons put uit die verlede en ons moet bewaar wat uit die mooi tradisie tot ons kom. Weet $u$ wat dit is? Wel, dit is een van die magtigste en mees moedgewende eienskappe wat die gelowige ten deel val en wat net hy kan uitspreek.

Ons geskiedenis spot met elke vorm van berekening. As 'n held eers alles gaan bereken, haarfyn sy kanse om te slaag gaan besyfer, sou daar waarskynlik, nee, al te seker, geen held ooit gewees het nie. Elke heldedaad spot met elke vorm van berekening. Dit is juis die onberekenbare wat die oog van ander op so 'n daad trek en dit laat bewonder.

$\mathrm{U}$ moet my toelaat om enkele voorbeelde uit 'n oorvol geskiedenis en tradisie op te noem, sodat ons moed kan vat in die krisis waarin ons nou, heeltemal teen ons wil, gewerp is.

As Jan van Riebeeck alles bereken het, sou hy en sy metgeselle nie die reis met drie bootjies begin het nie, sou reeds vantevore Diaz en De Gama ook nie ons land ontdek het nie. As Piet Retief alles gaan bereken het, sou hy nie met Dingaan onderhandelings begin het nie. As Dirkie Uys alles bereken het, sou hy nie 'n heldedood gesterf het nie. As die onberekenbare Dingaansdag van 16 Desember 1838 ons tref, staan ons net versteld. As Paul Kruger die grot binnegaan om te onderhandel, spot hy met alle berekeninge. As ons 'n verenigde Suid-Afrikaanse Republiek in 1961 verkry, was dit ver wat enigiemand kon bereken of voorspel.

Sindsdien is daar telkens openbarings van onvriendelikheid, dikwels van eie bodem. Dikwels het ons te doen met ons eie landgenote wat bereken wat ons kanse is, nou dat ons voor 'n magtige getalle-oorwig staan. 'n Ganse wêreld het hom teen ons geskaar en die wêreld-opinie word gelei deur 'n onsimpatieke beriggewing en pers. Die miljoene van Afrika word teen ons gekondisioneer en 
van hulle word gencem om onderrig te ontvang in ondermynende bedrywighede. Hulle moet dan kom, sogenaamd as die soldate wat vir vryheid veg.

Bereken nou ons kanse en elke berekening sal aan $u$ sê dat dit nul is. As ' $n$ mens telkens moet hoor dat ons weermag goed toegerus is en gereed, is dit ook op die grondslag van berekening 'n druppel aan 'n emmer en 'n stoffie op 'n weegskaal.

En tog gee ons nie moed op nie. Ons hou aan om ons standpunt te stel en om vir ons regte op te staan. Ons wil nie bereken nie, want ons bly een met ons geskiedenis. As alles eers moes bereken word voor dit begin is, sou daar van 'n Afrikaanse volk geen sprake gewees het nie. Die geskiedenis bewys juis dat wanneer ons volk in die grootste krisis gewerp is, ons oorwinning ook die grootste was.

Ek wil beweer dat hierdie weiering om op grond van berekening beslissinge te neem, uit die Bybel geput word en wil beweer dat dit die redding van ons volk was en bly, dat hy wysheid put uit hierdie enige bron.

Hoe sou Moses Israel ooit kon bevry as hy alles bereken het en hoe sou Israel ooit 'n selfstandige volk in eie land kon word, op grondslag van menslike berekening? Maar laat my die mees in die ooglopende Bybelse feit noem: As Dawid aankom waar Israel besig is om te veg teen die Filistyne, hoor hy die uitdaging van Goliat. die reus uit Gat. Die ander manskappe en Saul het dit ook gehoor, maar hulle berekeninge het duidelik voorspel dat geen mens enige kans het teen hierdie geharde en reusesoldaat nie. Daarom het hulle maar op die flanke elke dag geveg en hulle doof gehou vir die woorde van Goliat. As Dawid sy voorneme te kenne gee, is sy eie broers kwaad. Saul bereken ook sy moontlikhede en sê: jy is sommer 'n seun. Voorts bereken hy dat Dawid minstens darem 'n kans het as hy Saul se wapenrusting van staal en sy swaard aan het. Ja, sien $u$, die wapens word ook fyn bereken en Israel het darem ook ' $n$ harnas. As Dawid dit aan het en so Goliat tegemoet gaan, dan stap daar 'n miniatuur-Goliat na 'n reuseGoliat. Berekeninge beland ' $n$ mens soms in snaakse situasies.

Maar Dawid wil niks bereken nie. Hy gaan met gewone wapentuig, wat hy baie goed ken vanuit die herderslewe. Hy gaan eintlik met niks en dan hoor ons hoe hy spot met elke berekening: Ek kom na jou in die Naam van God. Opeens word alles vir ons duidelik. Die hele Bybel word ook vir ons duidelik en ook die beslissinge van ons helde uit ons geskiedenis. Ook Geloftedag spreek duideliker taal, want ook daar staan geskrywe: GOD. God kan nie bereken word nie, maar het God al teleurgestel?

Roeping is van God. Ons krag wat onberekenbaar is, is van God. Ons verlede spreek dat ons voorgeslagte met hulle oral saamgeneem het daardie Boek wat hulle geleer het om op God te vertrou. Dit is ons roeping om conservatorium te wees en daardie heerlike kenmerke te troetel en te bewaar.

Ek sou nog baie van hierdie grondkapitaal kan noem wat só nodig is in ' $n$ volk se huishouding en dit maak hom sterk. $U$ het my gevra om praktiese metodes aan die hand te doen om te behou 
wat ons het. Dit is hier nie 'n moeilike taak nie, want dit is 'n saak van die huis en van die skool en van die kerk. Ouers en grootouers moet maar mondeling meedeel aan hul kinders dat hulle geroepe is om hierdie adel van die gees te bewaar. Ons maak juis die fout om hierdie roeping af te skuif op die skool en die kerk. Of ons gee aan ons kinders 'n boek en sê hy moet lees hoe God ons volk bewaar en gelei het. Dit is nie reg nie. As die ouer praat, kom met daardie woord nie alleen die feite wat die kind moet weet nie, maar ook die hart, die geloof, die vuur van die hart en die kind weet om dit aan sy kinders eendag ook oor te vertel. Ons huise moet almal weer tempels word waar die geloof praat, waar die volkshart klop, waar 'n conservatorium gevind word van hierdie onwrikbare elemente, wat elke volk onwankelbaar maak. Ons retireer nie, maar staan bymekaar en beweeg elke dag vorentoe.

II. Observatorium.

Ons praat hier van 'n uitkyktoring, waar iemand op wag staan. As $u$ hier praat van die wese, die metodes, die program en die aanslag van kommuniste op ons, en ek moet antwoord, dan is die antwoord ook hier: moenie bevrees wees nie: die Christen is wakker, bedags of snags, vroeg of laat. Hy staan op die uitkyktoring en hou self ook wag.

Ons besef dat daar baie wagters is, die polisie, speurdiens, ons weermag. As ons hier spreek dat dit die Christen se roeping is om observatorium te wees doen ons dit weer om $u$ te wys op die dinge wat van die Christen 'n goeie wagter maak, 'n mens wat nooit slapend betrap kan word nie, een op wie sy volk kan vertrou.

Ook hier het ek ' $n$ beeld uit die Skrif en al dadelik besef $u$ dat die woord "wagter" glad nie vreemd is aan die Christenmens nie. Dit is 'n deel van sy mondering. Christus het in sy gelykenisse heelwat gespreek van hierdie wagters. Salig is hy wat die Meester wakker sal vind as $\mathrm{Hy}$ kom, al kom hy laat in die nag of met dagbreek.

Die beeld wat ek voor $u$ oproep is van 'n Bybelse stad, Jerusalem. Hierdie stad het 'n tempel gehad wat bo-op 'n berg gestaan het en dan was daar 'n muur rondom die stad. Die muur was nie rondom die tempel nie, maar wyd om die stad en het al die inwoners van die stad ingesluit om hulle beveilig teen aanslae van die vyand. Bo-op die muur was daar wagposte of wagtorings en daar het die wagters gestaan om tydig die volk daarbinne te waarsku as hy merk dat die vyand in aantog is.

As die Christen moet antwoord op die bedreiging van kommunisme, kan hy spreek van hierdie roeping, want hy besef dat as die muur val, dit ook klaarpraat is met die kerk daarbinne. As die Kommunisme sy oorwinning behaal, kan die Christelike kerk tog nie bly voortbestaan nie.

Wat gebeur daar nou? Die profete sien dit as hulle roeping om wag te staan op die muur. Hulle waak nie maar oor die kerk of Christendom nie, maar oor die ganse volk, omdat die kerk éen is met die volk waarbinne hy staan.

Die eienaardige is nou juis dat die muur van Jerusalem nooit geval het nie. Eers het die volk slap geword, veral in hul verhou- 
ding tot hulle God. Hulle verlaat God en stel belang in afgode en dan geskied die onvermydelike gevolg. God het dit ook aangesê: wie My verlaat, het smart op smart te vrees. Dikwels lees ons dat Gods volk Hom verlaat het en daarom kom die vyand en vind dat die muur brokkel. Die beste weergawe van hierdie waarheid vind ons in Jesaja $30: 13$ : „Daarom sal hierdie skuld vir julle wees soos 'n los stuk wat wil val, wat oorhang in 'n hoë muur, waarvan die instorting heeltemal onverwags kom".

Die profeet sê hier: die vyand daarbuite is nooit die eintlike gevaar nie. Natuurlik moet 'n mens wagstaan en gereed wees. Maar jy kan hom sien en jou verdediging daarop instel.

Die groot gevaar is as die muur begin oorhel na buite, as dit uitboggel, soos 'n sweer wat wil oopbreek. Die beeld sê dat die gevaar sit nie buite nie, maar binnekant die muur. As die vyand buite 'n aanslag doen, sal die muur binnekant toe val. Hierdie muur val buitekant toe en daar is dus vyande binne. Daarvoor moet ons op ons hoede wees, want dit is ' $n$ vyand wat jy nie kan sien aankom nie. Jy het hom saam met jou ingesluit. Noem dit inwendige verrotting, geesteskapitulasie, geestelike verbastering, verloëning van jou dierbaarste en verraad teen jouself. Sommige mense praat van geesteserosie, waar mense geleidelik hul eiendomlikheid prysgegee het en nou nie meer anders kan wees as 'n vrugbare bodem vir vreemde propaganda nie.

Wil u voorbeelde hoor van sulke vallende mure, na buite? Gaan lees maar die geskiedenis van die Grieks-Masedoniese ryk en van die magtige Romeinse ryk. $U$ kan maar meer na die moderne tyd toe ook kom en dan hoor 'n mens net altyd vallende stukke wat buitekant toe krummel. Die Bybel is waar: geen volk het nog ondergegaan deur aanslae van buite nie. Hy mag tydelik ontwrig word, maar hy rys telkens weer op en is sterker as tevore. Ons eie volk is daarvan ' $n$ klinkklare voorbeeld.

Dit maak die roeping om observatorium te wees des te moeiliker. Vir ons eie volk het juis die Christen hier 'n besondere taak en dit sal ons weerbaarheid verhoog as ons inwendig sterk staan, suiwer en gelouter. Ons wil $u$ wys op 'n paar eienskappe waar ons op moet toespits:

1. Binne ons volksmuur het telkens defaitisme tot openbaring gekom. Ook in hierdie krisisuur, net toe die druk heftiger word en daar sprake is van offers wat gevra sal word, het ons emigrante gekry, landverhuisers, wat om eie veiligheid ontwil 'n ander vaderland gaan soek het. Natuurlik, toe die wolke weer verbygewaai het, het hulle weer teruggekeer. Dis mense met geen hart nie, of liewer met twee harte. Hulle verbind hulle nie met die hele hart aan die eie vaderlandsbodem nie. Daar is geen liefde nie. Selfs al sou hulle hier bly, sou hulle nog niks vir ons beteken nie. As hulle om hulle eie veiligheid ontwil op 'n vir hulle geleë tyd, verkies om hul land te verlaat, sal hulle, as hulle bly, om dieselfde rede aan die kant van die vyand gaan staan en daar geen kwaad in bemerk nie. Hulle is dus mense wat binne die volksmuur is, maar wat dit buitentoe sal laat val.

Hierdie mense is ook die maklikste prooi van die kommu 
niste, want dit is juis waarop hierdie vyandige propaganda mik. Internasionale Kommunisme soek internasionale geeste wat oral tuis kan wees en niks het waaraan die eie hart aan verbind kan bly nie.

2. Die tweede saak wat onder die onderskeidende oog moet bly, is juis die internasionalisme en al sy broederskappe wat sodanig vermenigvuldig dat dit ' $n$ mens daarop bedug maak dat jou volksmuur met al hierdie elemente miskien kan dreig om buitentoe te val. Wanneer nasionalisme as ' $n$ euwel beskou word en internasionalisme verheerlik word, verkry 'n mens persone wat nie meer saam met jou wagstaan oor die volkseie nie. Nou hoor 'n mens nie meer van 'n eie aanhanklikheid nie en daar word nie meer in die enkelvoud gepraat van my land en $m y$ volk en $m y$ taal nie. Nou word in die meervoud gepraat van ons land en ons taal, ons verantwoordelikheid en ons erfdeel.

Ek gaan hierdie internasionale broederskappe nie noem nie, maar wil my vrees uitspreek dat ons hier 'n bedreiging het. Nasionale dinge by ons word beskou as eng en uitgedien. Ons hoor van 'n Internasionale taal, Internasionale burgerskap en ons het nou ' $n$ internasionale demokrasie met sy kreet van: een man, een stem. Alle nasionaal-eie moet hiervoor wyk. Dit is die heel grootste en eintlik die saamgevatte weelde dat ' $n$ mens moet kan stem. Hy kan sonder voedsel, sonder medisyne, sonder beskawing, sonder kultuur, sonder beginsels - solank as wat hy net kan stem. Die Kommunisme het daarin geslaag om 'n slagwoord te verkry en hierdie slagwoord word oor en oor herhaal, ook deur anti-kommuniste. Nou geld dit as die internasionale bewys van goedgesindheid. Al het Rusland van die voorreg van die stem 'n lagwekkende klug gemaak, tog geld dit as enigste eis.

3. Die derde saak is seker die heel belangrikste: geluk binne die volksmuur en ' $n$ aanvaarde beleid, veral wat betref ons gekleurde bevolking. Hier sluit ek alle volke in binne ons grense. Hulle word oral as hefboom gebruik om ons binne die koue oorlog te betrek en die sogenaamde kampvegters vir hulle belang, is byna almal erkende en gelyste kommuniste.

Die Christen wat staan op sy wagpos is die enigste aanspraakmaker op die eer en voorreg om aan die Bantoe, die Indiër, die Kleurling, leiding te gee. Hy is nie 'n rewolusionis nie, wil nie omverwerp nie, kan nie toesien dat onreg moet geskied nie en moet ongelukkig wees as hierdie groot bevolkingsgroep ongelukkig moet wees. Sy roeping, van die begin af aan beklemtoon, is om hierdie groepe sódanig te oortuig van ons goedgesindheid en dat 'n ideaal vir hom en sy nageslag duidelik nagestreef word, dat die Bantoe en sy gekleurde metgeselle nie ' $n$ bron van gevaar nie, maar die grootste bondgenoot kan wees.

Dit is inderdaad glad nie bitter moeilik om dit te verrig nie, want ons ken mekaar, leef al vir eeue saam met mekaar, werk saam op plase en fabrieke. Ons het ook 'n tradisie van regverdigheid wat net verder ontplooi moet word. Ons het ons altyd genoem voogde en moet nog altyd bly, sodat ons 'n beletsel kan wees vir die parasiete wat die Bantoe wil uitbuit vir vreemde belang. Dan moet ons ook bereid wees om te besef wanneer die tyd van ont- 
voogding aangebreek het, sodat ons as volwasse bondgenote kan saambestaan. Ons moet die Bantoe nou al leer wat ons bedoel met vreedsame saambestaan, wat ons bedoel met goeie buurskap. Ons moet aan die Bantoe, Kleurlinge en Asiatiese groepe sê wat ons eintlik nooit gesê het nie. Ons het jou lief en ons doen hierdie dinge vir jou omdat ons jou nodig het in die ontwikkeling van hierdie groot land. God het jou hier geplant en niemand mag jou hier wegneem nie. Jou nageslag moet trots daarop wees dat hy kind van Suid-Afrika is. Jy het met jou krag en arbeid, met jou sweet en handearbeid, ons myne ontgin, ons lande geploeg, ons in staat gestel om self eers heel primitief ons voete te vind in die industriële lewe. Ander het ryk geword uit jou arbeid, maar baie ander het maar net saambestaan en aan die lewe gebly. Noudat die Afrikaner ook sy kop uitsteek bo die allernoodsaaklikste wat sy inkomste en reserwes betref, nou wil hy ook aan jou gee om meer as die allernoodsaaklikste te geniet. Jy kry nou jou goeie huis en woning, jou ontwikkeling tot meer nuttige arbeider, jou hoër verdienste. Ons kan self ook nog nie ons eie toekoms goed sien nie, maar ons het nie 'n toekoms en ons wil ook geen toekoms sonder jou, swartman en bruinman van Suid-Afrika nie. Ons sal afweer enige vyand wat jou aanval, jou jou regmatige regte wil ontneem, jou ekonomiese regte jou wil ontneem, jou staatkundige regte waartoe jy al mooi ontplooi het, te vervreem. Ons moet ook hierdie mense aan die kaak stel wat nou so 'n verraderlike spel speel met ons Bantoes, sodat hulle deur Bantoes self uitgewerp kan word. Hulle weet ook dat hulle 'n uiters gevaarlike spel speel en dat die dag van afrekening nie meer ver is nie. As ' $n$ mens se tyd kort is, dan gaan jy so histeries te kere, soos wat ons vandag hoor en sien. Jou beloftes is totaal buite verhouding met jou moontlikhede. Hierdie agitators het ingesien wat ons lankal weet, dat die Bantoe 'n kind is, liggelowig, goedvertrouend. Maar as hy eers ontwaak het en insien dat hy mislei is, is hy net so 'n onkeerbare vyand. Dan laat hy net met die dood boet.

Aan die Bantoe word beloof stemreg en nog oneindig meer, want saam met die stemreg kan hy 'n motorkar ook kry. Aan hom word beloof vryheid en saam met vryheid ook eie plase en rykdom. Aan hom word beloof selfregering en selfbeskikking en daarmee saam dat hy beskikking kan kry oor al die werkplekke, al die fabrieke en inkomste, al die myne en die goud.

Eers as die Bantoe besef dat om 'n myn te hê net beteken dat jy 'n klomp finansiële probleme het, dat die goud werklik daar is, maar nie opgetel kan word nie, eers dan sal hy besef dat hy bedrieg geword is en dan kom die dag van afrekening. En veral as die dag aanbreek waarin hy by hierdie agitators die regte selfsugtige stem hoor: Gee jouself aan my, gee aan my jou vryheid, jou stemreg en selfbepaling, want ek wil jou een van my gewillige satelliete maak, slaaf van my soort willekeur, wat werklik wreed is - dan sal die omkeer kom.

Ons verkeer in so 'n gunstige posisie, omdat ons vir niks hoef skaam te wees nie. Ons kan hier en daar fouteer en het seker al in die verlede verkeerde dinge gedoen en is sekerlik skuldig aan baie 
nalatigheid. Tog het ons al veel ingehaal. As ons die stryd verloor wat ons voer ten gunste van die Bantoe, teen die agitators, sal dit werklik ons eie skuld wees, en dit sal ons ondergang wees. Dit beteken dat ons ondergang ook ons lot moet wees, en meer nog: ons skuld.

Ek het hierbo gepraat van mure wat brokkel en buitentoe val. As dit nie regkom met ons verhouding tot ons nie-blankes nie, en hulle ons nie aanvaar as hulle weldoeners nie; as hulle ons nie vertrou nie en nie positief die anti-Suid-Afrikaanse propaganda teenwerk en stuit nie; as hulle nie saamwerk om die oproerige elemente wat kwaad smee teen ons Republiek aan bande te lê nie, sal die mure buitentoe val. Immers, as die Bantoe deel van Suid-Afrika is, soos hy wel is, is hy binne die volksmuur en moet hy ons bondgenoot wees.

Die Christen antwoord hier: ons moet ons minder bekommer oor die buitelandse opinie en oor V.V.O.-intriges. Ons moet ons toespits op ons eie werf en die oog rig op diegene binne ons volksmuur. Ons moet 'n gelukkige blanke en Bantoevolk hê. Ons moet die Kleurlinge aanvaar as ons naaste wat saam met ons beweeg op ons nasionale pad tot ons eie Suid-Afrikaanse bestemming. Ons moet geregtigheid doen teenoor die Indiër en hom gelukkig laat voel.

Dan het ons ' $n$ bolwerk, 'n sterk vesting wat nie sal en kan brokkel nie. Ons hoef nie bevrees te wees vir die leuenpropaganda nie. Aristoteles het eeue gelede al gesê: moenie jou bekommer as ander jou beskinder nie; leef so dat niemand hulle glo nie.

4. Die Christen wat op die wagtoring staan moet ook nousienend wees dat geregtigheid betrag word en billikheid moet die wagwoord wees. Hiermee gaan natuurlik gepaard dat waarheid beoefen moet word. Is daar 'n gebied wat nader aan huis is, as hierdie geestelike terrein wat deur die Christen nie net gepreek word nie, maar ook beleef? God is die hoogste waarheid en God is 'n God van geregtigheid. Geen mag, geen vereniging of Bond, ook geen regering, mag die Christen van hierdie mooi pad af laat gaan nie. Dit is beginsels hierdie wat sodanig die eiendom is van die Christenmens, dat dit sy lewensasem genoem kan word. Gee die waarheid prys, en jy beland in dieselfde impasse as die Kommunisme, wat deur niemand meer vertrou kan word nie. Waarom is dit dat volkere nie tot oplossing van hul vraagstukke kan kom nie? Die antwoord is eenvoudig. Hulle mag saamstem, maar ook die saamstemming het nie veel betekenis nie, omdat kommuniste God nie vrees nie, en daarom geen groot agting het vir waarheid, geregtigheid en billikheid nie. Al wat ons hier eis is dat die Christen getrou moet wees aan sy wese.

In die praktyk verg dit sekerlik in 'n hoë mate selfverloëning. As jy geregtigheid en billikheid van ander eis, is dit jou roeping om dieselfde ook aan ander te doen. Dit is die eis van blote beskawing en kultuur, omdat dit die geringste is wat een mens teenoor 'n ander kan bewys. By ongeregtigheid kan geen mens bly leef nie, omdat ongeregtigheid tot opstand moet bring, tot weerstand, tot afwerping van ' $n$ ondraaglike juk. By ongeregtigheid verdwyn alle liefde en onderlinge verhoudinge. Ja, liefde is ' $n$ baie mooi, maar 
teer blommetjie, wat gekoester moet word deur die lug en liefde van geregtigheid; maar ongeregtigheid is 'n yskoue rypwind wat onmiddellik laat verlep en verdroog.

Hier eis ons baie.

Ons is ook bereid om baie te gee. Ons het immers veelvuldige geleenthede daartoe en ons hoef ook nie ver buite ons grense te kyk om dit te kan doen nie. Ons kan maar kyk na diesulkes wat elke dag ons paaie kruis. Ons moet as Christene op die uitkyk wees dat geregtigheid en billikheid aan ons Bantoes en gekleurdes bewys word. Ons is tog geregtigheid verskuldig aan hulle wat God by ons en langs ons geplaas het om saam in een land te woon. Hulle moet naarstiglik met billikheid behandel word omdat hulle dit so nodig het. Sonder dit kan daar geen toekomstige goeie buurskap en gelukkige saambestaan wees nie.

Ons wil natuurlik ook veel ontvang. Bantoes en gekleurdes kan dikwels net soos kinders wees wat baie selfsugtig kan wees. Hulle dring altyd op meer aan en is nie maklik tevrede nie, maar hulle wil niks gee nie. Geregtigheid is wederkerigheid. As dit ooit mag blyk dat ons betoning van geregtigheid nie gewaardeer word nie, maar misbruik word, dan kan geregtigheid verskriklik brand, word dit 'n vuur wat nie ophou brand voor alle ongeregtigheid volkome uitgebrand is nie. Daarom moet ons versigtig handel, nie sommer aan wilde spekulasies ons oorgee nie, nie elkeen sy eie hoof navolg nie, nie maak asof ons die volle wysheid in pag het nie.

III. Laboratorium.

Dit is die werkplek en die Christen moet die beste werker wees, omdat hy nie werk om die oog van die baas te bevredig nie, maar omdat God sy Here en Meester is en hy wil Gode behaag. As die Christen antwoord moet gee in hierdie tydsgewrig en moet opsom wat gedoen moet word, kan hy nie net tevrede wees om te sê dat ons 'n conservatorium moet wees nie, en dat ons ' $n$ observatorium moet wees nie. Dit sou beteken dat ons slegs op die reserwekapitaal moet teer wat uit die verlede na ons toekom. Hoe noodsaaklik dit mag wees om moed te gee en versekerd die grondkapitaal oop te dek, is dit nie al nie. Ons kan ons nie net in geestelike dinge ons krag soek nie, wys op wat gedoen behoort te word nie. Dan sou die Christen gewoonweg op die wal staan en daarvandaan sy instruksies gee aan ander, maar self nie inspring om te werk nie.

Laboratorium wees - tuis in die werkplek - daar waar die roeping uitgevoer moet word, daar waar dit elke dag 'n werkdag is, daar waar dit nie maar gaan om my daelikse loon nie, maar om eerlike, noeste vlyt.

Laat ons verseker weet dat die kommuniste gekom het waar hulle is, deur arbeid, volgehoue werk en prestasie. Ons het hier te doen met ' $n$ mag wat nie op die rug van iemand anders daar gekom het nie, maar deur self die rug krom te buig en alle kragte in te span. Ons moet onthou dat ons hier te doen het met 'n ideologie wat nie die geld of kapitaal verheerlik nie, wat nie die Staat voorop stel nie, maar wat as slagwoord genoem het: arbeid is kapitaal. Dit was dus geen geldkapitalisme nie, maar 
arbeidskapitalisme. Die werker is verheerlik as skepper, moontlikmaker van 'n toekoms. Die arbeider moet dus nie net die loon op sy werk ontvang nie, maar moet ook die verantwoordelikheid hê van die staatsregering. Vandaar dat in Rusland 'n rewolusie gekom het wat die onderdrukte arbeider verhef het tot toonaangewende groep. Rusland het onteenseglik bewys dat die arbeider in enige staat die toekoms in sy hande het.

Kommuniste het hulle ryk en hulle toekoms gebou op 'n laboratorium. Dit was geensins net 'n laboratorium van kraginspanning nie, maar ook van fynste breinkrag waarvan hulle ruimteprestasies seker goeie getuienis gee. Laboratorium te wees, met middele wat nooit te kort skiet nie, omdat die Staat se prestige hiervan afhanklik is, is die krag van die Kommunisme, maar dit is tegelyk ook hul swakheid. Arbeid het hul godsdiens geword en arbeidsprestasies word nie diensbaar gestel aan die mensdom nie, maar om Rusland 'n bedreiging te maak vir alle ander lande. Arbeid beteken oorwinning en oorwinning kan nie bereik word deur oorlog nie, maar deur koue oorlog. Arbeid bind dus nie, maar skei veeleer, omdat dit die middel is om die koue oorlog des te duideliker te laat voel. Nie net vertrou jy nie die ander volk nie, maar jy bly vreemdeling vir jou eie buurman. Yskoue waters van ongeloof, agterdog, geheime polisie, moet voortdurend gebruik word. Daarin kom die swakheid duidelik uit.

Wat antwoord die Christen?

Hy spreek ook van 'n laboratorium, en bedoel daarmee dat ons volk moet weet om moue op te rol en hard te werk, baie harder te werk as tot hiertoe. Ons moet weer aan mekaar sê dat elke burger moet, juis omdat ons $\mathrm{min}$ is in getal, drie man se werk doen, maar net een man se loon ontvang. Die onderwyser wat net bedags in sy skool staan of met skoolwerk besig is, doen nie sy werk nie en trek nie sy volle gewig nie. Die predikant wat net met sy gemeentewerk besig is, mag 'n baie goeie predikant wees, maar hy doen nie sy volle taak nie. Elkeen wat klaarkry met sy plig, sodra as sy spesifieke taak verby is, is nie goed beset vir sy taak nie. Ons moenie so gou moeg word nie en nie altyd pleit om meer vakansie nie. Die Christen se antwoord op die kommuniste se la. boratorium is: 'n beter laboratorium, waar vry en selfstandige manne en vroue uit liefde hulle werk doen. Dit gaan ons nie net om 'n diens aan land en volk nie, maar 'n dienskneg en diensmaagd te wees van God en om wêreldwyd dienstig te wees.

Werk en laat werk. In hierdie tydsgewrig waarin ons leef, is dit die antwoord van die Christen aan die baie doelgerigte aanvalle op ons ekonomie. Hoe dankbaar moet ons wees dat ons werkbanke $100 \%$ beset is met bestellings. Hoe dankbaar moet ons wees dat daar geen teken is van afname nie, maar dat nog steeds aangedring word op groter produksie en dat die produksie nie vir wapens ter vernietiging is nie, maar hoofsaaklik vir voedsel en kleding. 'n Volk wat besig is, het nie tyd vir ondermynende gedagtes en beplanning nie.

Ons moet jaloers wees op ons status en jaloers op ons voorreg om in Afrika 'n kragtige en steeds voortstuwende industrie te wees. 
As ander state na ons verwys en dreig met boikotbewegings, kan dit alleen verklaar word uit ' $n$ poging om ledigheid te bewerkstellig, sodat daar voldoende oproerige elemente kan wees om te organiseer. Dit is duidelik dat dit nie geskied omdat hulle teen ons rassebeleid gekant is nie, want eintlik slaan hulle juis die Bantoeras, wat hulle wil beskerm, die hardste. Nee, hulle wil ons laboratorium van arbeidsprestasie belemmer, die werkers se werk hulle ontneem. 'n onheilige plan om werkloosheid te bewerkstellig, sodat Kommunisme op hierdie aas soos 'n jakkels kan toeslaan. Hier het ons nie die koninklike plan van 'n leeu, wat eg majestueus sy prooi bespring en vang nie. Hier het ons inderdaad die sluwe jakkals wat op laaghartige wyse leef van deursigtelike slinksheid. Hy sal teer op die swak lammertjies wat hy middernag besluip.

Kan $u$ begryp dat ons laboratorium-antwoord ' $n$ eerlike antwoord moet wees, wat nie net die oog het op die blanke arbeider nie, maar dat ons met ons saam moet voer elke werker en dat dit ons roeping is om elke werker ' $n$ bekwame arbeidskrag te maak wat bereid is om die allerbeste prestasie te lewer en waar hy moet leef uit sy arbcid, dat sy arbeidsdag so lank as moontlik moet wees, en sy ouderdomsdag ook verseker mag wees. Ons moet met ons geesdrif en entoesiasme op mars gaan en met ons saamneem clkeen wat by ons behoort. In ons pers en oor ons radio moet die oproepe weerklink dat ons voortdurend ' $n$ tekort het aan werkkragte en dat alle werksbanke wag om tenvolle beset te word met werkers wat saam wil werk.

Dit is ons antwoord aan die wat ons werk ons wil ontneem: harder werk en meer werk. 'n Laboratorium wat soos ' $n$ bynes sing van arbeid en waar die werkbank dreun, dag en nag.

Ons wil as Christene antwoord op die bose bedoelinge wat ons verwyt dat ons geen toekomsplanne wat konstruktief genoeg is vir ons nie-blankes het nie. Al antwoord wat ons hier kan gee, is dat ons laboratorium nie volspoed sal kan werk as ons nie ons nie-blankes ten volle kan benut nie. Of ons, en ons kritici dit wil weet of nie, ons het meer werk as wat ons arbeidskragte het. Industrieë gaan nog in die naaste toekoms oormekaar val om arbeidskragte te bekom en dit sal self die arbeidsmark ten goede kom. Die arbeider is sy loon werd en elke eerlike arbeider wat ten volle sy gewig inwerp, kan nie anders as om homself onmisbaar te mak en sy eie loon hoog op te skuif nie. En daarom: ons wil nie ons nie-blankes wegwens nie. Ons is jaloers op hulle en SuidAfrika het miskien lank gewag om elke arbeider ten volle te betaal vir sy werk, miskien te lank gewag om die werkplekke gereed te maak wat vir ons en vir die wêreld so broodnodig is, maar nou dat hy op mars gaan met sy mooi industriële ontwikkeling, gaan niks hom meer keer nie. En die werkers kan daaroor gelukkig voel.

Ons moet dit duidelik stel dat dit nie die Afrikaner, die blanke is wat so lank uitgestel het met 'n deuglike ekonomiese struktuur nie, en wat dus verhoed het dat aan die nie-blankes 'n redelike en goeie verdienste gegee word nie. Dit is ook nie politieke rigtinge wat hiervoor die skuld moet dra nie. 'n Christen moet darem eerlik wees en erken dat ons land telkens moes verrys na 'n periode 
van verdrukking. Miskien sou dit baie meer billik wees om te sê dat baie van die mense wat vandag so skreeu oor boikotte en so meer, die skuld moet dra dat hulle nie ons gesteun het om werkplekke te bekom wat uitkoms kon bied vir al ons blanke en nieblanke werkers. Dit is ook blankes wat heel kort gelede nog maar 'n uiters karige loon verdien het en eintlik hulleself nie kon help nie en daarom ook nie nie-blankes op sleeptou kon neem nie. Maar toe ons die nuwe tydperk betree, het blank en nie-blank volkome saam beweeg en sal in die toekoms al hoe meer op die patroon beweeg.

Die Christen se antwoord is nie verdedigend en negatief nie. Hy glo in God en weet dat sy land en volk, sy taal en kultuur, sy liefde en hart altyd moet hê.

Daarom is die antwoord van die Christen heerlik positief, verhewe bokant die daelikse gemor en onderduimsheid. Ons oog is gerig op God en om ons heen. Ons waardeer die verlede, ons is wakker en gereed in die hede, ons is werklustig en entoesiasties vir ons roeping.

Conservatorium - Observatorium - Laboratorium.

So staan die volksmuur en word hy elke dag sterker.

Die verlede het aan ons die muur gegee.

Ons staan in die hede wag daaroor.

Ons bou - sodat ons dit ongeskonde kan oorhandig aan die nageslag. 